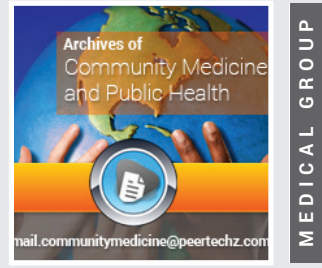

\section{Deane Waldman*}

MD, MBA, Emeritus Professor, Department of Pediatrics, Pathology \& Decision Science Former Director,Center for Healthcare Policy, Texas Public Policy Foundation, USA

Received: 18 September, 2019

Accepted: 18 October, 2019

Published: 21 October, 2019

*Corresponding author: Deane Waldman, MD, MBA, Emeritus Professor, Department of Pediatrics, $\mathrm{Pa}$ thology \& Decision Science Former Director, Center for Healthcare Policy, Texas Public Policy Foundation, USA, E-mail: dw@deanewaldman.com

https://www.peertechz.com

\section{Check for updates}

Clinical physicians believe they are drowning . . . because they are! Between complying with an ever-changing landscape of time-wasting federal regulations, avoiding Health Insurance Portability and Accountability Act violations, plus the entire billing process, who can keep up with the literature, study a patient's medical history, or even talk with a patient?

Yet, here I am adding another task to a plate already overflowing. Doctors are turning their backs on the sickest patient of all, named U.S. Healthcare System. The current attending physicians-Congress-have been treating this patient for more than fifty years. More accurately, they have been poisoning the patient for half a century.

Consider what their treatments have done to patient Healthcare. In 1960, the U.S. spent five percent of Gross Domestic Product (GDP) on healthcare. By 2026, when Medicare goes broke [1], we will be spending \$5.5 trillion [2], 20 percent of GDP, which nearly equals the entire 2018 GDP of Japan, \$5.2 trillion. Close to half of all U.S. healthcare spending produces no care, as it goes to federal BARRC: bureaucracy, administration, rules, regulation, and compliance [3].

According to a Merritt Hawkins survey [4], the average maximum wait time in 2007 to see a primary doctor was 100 days: ten years later with the Affordable Care Act implemented, it was 176 days. Before Obamacare, the national acceptance rate for Medicaid patients was 74 percent. Now, it is 55 percent.

Patients are asking why they can't get care, certainly not timely care. The answer is cancer. Cancer is consuming both the money for patient care and physicians' time to care for their patients. Location of the primary malignancy is clear, Washington, though it has metastasized diffusely.
There are literally innumerable examples to prove that the cancer in healthcare is federalization. I will limit myself to three.

Rhode Island and Montana have the same populations, one million residents each. Rhode Island has 5146 physicians within its 1212 square miles. There are three world famous medical centers less than one hour's drive of Providence, R.I. Montana has 1100 doctors scattered over 145,000 square miles. From the capitol in Helena, Montana, the nearest major medical and trauma center is more than eight hours away in Salt Lake City, assuming the roads are passable. Despite these differences, Washington mandates a one-size-fits-all approach in both states.

Spending on Medicaid is either the largest or second largest budget item in every state budget. According to the original 1965 Medicaid law, programs are supposed to be "administered by the state." Yet federal mandates administer all state programs-Washington decides where state money goes, not the state residents through their legislators.

With federal healthcare comes federal bureaucracy and its insane complexity, such as the International Code of Diseases -10 code book. There are approximately 1400 ailments and injuries that befall humans. The code book to bill for care contains more than 68,000 codes, such as W55.21 (bitten by a cow), W61.33 (pecked by a chicken), Voo.01 (pedestrian on foot injured in collision with a roller blader), and Y92.146 (injured at a swimming pool within a prison).

The cancer in healthcare is a bipartisan affair. Both Republicans and Democrats are guilty of poisoning patient Healthcare. To be fair, Democrats' Obamacare doubled the dose of poison. Their Medicare-for-All, H.R. 1384, bill would put healthcare in a coffin [5].

\section{Expecting Washington to fix healthcare is like waiting for cancer to cure cancer [6]}

Washington will never cure patient Healthcare. Someone else has to do it. Who will? The only power greater than Washington is We the People, or as I like to write, We the Patients. They need guidance from their physicians. Doctors understand better than anyone else that sooner or later, everyone is a patient. Republicans, Democrats, and Independent; whatever your skin 
color or religion; no matter where you reside; and regardless of income level, eventually, everyone needs medical care. We the Patients are the one sure stakeholder. We the Patients have the power-if We will use it.

Doctors know how to cure a patient, any patient, whether human, animal, or sick system. Identify the root cause and cure that. If a patient has an infection, you give an antibiotic specific to the infectious agent. If a patient has a blocked coronary artery, you unblock it. If a patient has cancer, you cut it out, even if the patient is named Healthcare.

To cure patient Healthcare, excise Washington. Return freedom to the people. Release the free market that made this country great. Restore the direct connection between doctor and patient.

\section{Return freedom}

The U.S. was founded on the singular principle of freedom: from control by a central authority and from the constraints of a structured class system. With that freedom comes a variety of choices, the potential for unlimited individual success, and personal responsibility.

In 1776, we freed ourselves from a tyrannical aristocracy. Today, by accepting government entitlements, we seem to be drifting back toward tyranny, this time by the professional political class.

Americans should be free to choose their care providers, free to decide their own medical care, and willing to accept the consequences of their choices. Americans should be free to control their own spending without a third party, government or insurance, dictating where patients' money goes and how much money they expend supposedly on patients' behalf.

US healthcare should be free from federal control, not only because of Washington's poor track record but on legal grounds as well. The Tenth Amendment to the Constitution states that Washington should not have "power" over healthcare. "The powers not delegated to the United States [federal government] by the Constitution, nor prohibited by it to the states, are reserved to the states respectively, or to the people." Healthcare was not delegated to the federal government. With five doctors as signatories to the Declaration of Independence and many more physicians as members of the Constitutional Convention, the founding fathers did not simply forget about healthcare. Washington was never supposed to control healthcare.

\section{Release the market}

U.S. healthcare has arrived at an unenviable state: spending too much and getting too little. In 2018, the average American family spent $\$ 28,166$ [7], 39 percent of their total income, on healthcare, mostly for insurance premiums, which more than doubled due to Obamacare.

Both our veterans [8] and Medicaid enrollees [9], are experiencing death-by-queueing: dying while waiting in line for care. And when Medicare goes broke by 2026, seniors won't be able to get hospital care [1].
Clearly, Americans are spending more on healthcare and getting less care despite decades of Washington fixes.

With any centrally controlled market, whether for services like health care or goods like bread and soup, costs invariably rise while quality and availability fall. Two recent examples are the now-defunct U.S.S.R. and the failing nation-state of Venezuela, both of which had centrally determined production, prices, and wages; prohibition against private property, and elimination of profit motive, just as proposed in Medicare-forAll, H.R. 1384 [5].

The U.S. has not had a free market in healthcare since the creation of third-party payers, government and insurance (supported by federal mandates) in the 1930s. Any free market depends on the direct connection of buyer (patient) and seller (service provider or manufacturer). The buyer decides whether to buy or not, how much to pay, and to whom. Since they are paying out of their own pockets, buyers have a powerful incentive to economize. Sellers have to compete for buyers' dollars based on price and quality. If prices are too high or quality not satisfactory to buyers/consumers, the seller fails to sell his products or services.

In a free market, there is constant downward pressure on prices, competition to produce the highest quality, and a compelling reason not to spend. When a market is centrally controlled, as U.S. healthcare today, the exact opposite occurs, as Americans have experienced. Prices rise to unaffordable levels and then keep rising. Competition is fierce, but for contracts not service to patients. Access to care goes down, and down. As providers are devalued, their payments degrade. The incentive is to increase spending-on BARRC not on patients, on bureaucrats rather than doctors.

The solution to healthcare's death spiral starts by cutting out the cancer that is Washington. Obviously, Congress will resist reducing its own power. Only We the Patients can make this happen.

Doctors need to explain to their patients that healthcare has cancer and that there is a simple cure so Americans can get healthcare their way: StatesCare [10].

\section{States care}

Removing Washington from healthcare-StatesCare-brings the decision about healthcare down to the state level, where representatives are constant contact with their constituents and much more responsive to you and me. (Contrast to our Congressional representatives) (Figure 1).

If 28 million Texans want market-based medicine [10]; if 6 million residents of Washington state want their version of universal healthcare [11]; and if 39 million Californians want single payer [12], by what authority does the District of Columbia deny 73 million Americans the right of selfdetermination? While the evidence leads this author to conclude that single payer is an unwise choice [13], my opinion should count only in my home state. Let the people in their states decide- it's that simple. 


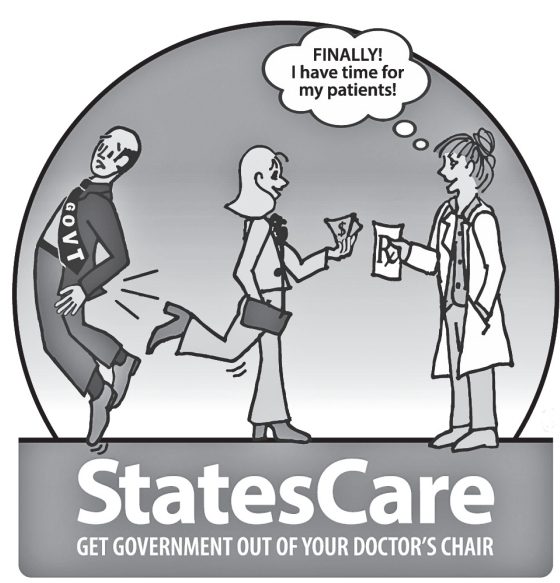

Figure 1: H) Waldman

When a resident of one state is visiting another state and needs care, reciprocal arrangements should be in place. This is a matter of negotiation that Americans would expect their states to accomplish. Furthermore, if a resident in one state strongly objects to the system chosen there, he or she is free to move elsewhere. People are already relocating because of state tax rates [14].

Excising Washington would also remove its massive and costly bureaucracy. Evidence-based estimates of the cost of the federal bureaucracy indicate more than 40 percent of healthcare expenditures go to BARRC. Since the U.S. spent \$3.5 trillion on healthcare in 2018 [15], $\$ 1,400,000,000,000$ worth of patient care was taken from the American people to pay for BARRC.

With StatesCare, Americans can recoup most of that money and either leave it in taxpayers' pockets or spend it on doctors and nurses instead of wasting healthcare dollars on bureaucrats.

\section{Restore doctor-patient connection}

The people in their states should decide the best healthcare for them. Doctors should urge restoration of the direct doctorpatient relationship without a third party in between, and release of the free market.

If Americans want to be free to make their own medical and financial decisions, they must reject entitlement in favor of personal responsibility [16]. If We the Patients want doctors who know them by name, who has studied their medical history, who will see them tomorrow not in six months, who have time to talk with them, then patients must control their own spending.

High deductible catastrophic insurance? By all means. Insurance making medical and financial decisions for patients? Absolutely not! Patients should have large HSAs that they control with no time limit for use. Patients shop for providers and care, and pay "cash" from the HSA. Providers would compete for buyer's (patients) dollars. Just like buying a car, patients would require not just prices but also positive outcome metrics, in a form they can understand. That is our job, if we want patients to purchase our services.

State residents should decide their own healthcare [17]. Doctors need to acquaint the public with the advantages of market-based medicine and return of the doctor-patient connection. It is likely that people would want a safety net for medically vulnerable Americans. There are viable options including high-risk pools and state-supplied HSAs.

As a demonstration, ask your patient if they would choose to continue paying more than $\$ 28,000$ to insurance companies and get whatever care some bureaucrat approves, or put the $\$ 28,000$ in their HSA, buy high deductible insurance, and pay for their own care out of the HSA?

Someone recently posed the following question on Quora, a dialogue website. "Why is it important for health care managers and policymakers to understand the intricacies of the health care delivery system?" The first answer is, invalid assumption. The question presumes that the care delivery has to be intricate, maze-like, and so complex that the ACA had to create a new class of bureaucrats, navigators.

Health care is not inherently complex. In fact, it is simplicity itself, or should be. One patient makes a contract with one doctor. Doctor provides service. Patient pays for service. Period. It is the incursion of the third-party as payer and decision maker disconnecting patient (buyer) from doctor (seller). Such disconnection turns a simple contract into a massive coding, billing, review, compliance structure of rules and regulations. The process of providing care has become intricate, maze-like and incomprehensibly complex, but it need not be. Simply reconnect patient and doctor.

\section{Conclusion}

Patient Healthcare System has cancer [6]. The primary is located in Washington but has metastasized diffusely. The cure for this cancer is to excise Washington and its ancillaries from healthcare. Let the people in their states decide what healthcare structure they want.

\section{Exhortation}

When I discuss the above ideas with other physicians, they generally concur. When I urge an active, leadership role in fixing healthcare, the same doctors demur. "We have no time! Our patients need us now. We simply can't do more."

The best response is a paraphrase of Rabbi Hillel's words from the book, "Ethics of the Fathers," written shortly before the common era. President Kennedy also emphasized this aphorism. "If not me, who? If not now, when?"

I exhort my fellow physicians to arm yourselves with the evidence and proofs in the book,

"Curing the Cancer in U.S. Healthcare [6]." Then, and more important, encourage patients to read the book. Only a groundswell from the American people can force Washington relinquish its tight grip on healthcare and return authority where it belongs: We the Patients. 


\section{References}

1. Mnuchin ST, Acosta AR, Azar II MA, Berryhill AN, Verma S (2018) Annual Report of The Boards of Trustees of The Federal Hospital Insurance and Federal Supplementary Medical Insurance Trust Funds. Link: https://go.cms.gov/2J1dAR7

2. Beaton $T$ (2018) National Healthcare Expenditures Expected to Reach \$5.5T by 2026 . Healthpayerintelligence.com Link: http://bit.ly/2BpNm6s

3. Waldman D (2015) The Cancer in the Healthcare System: How Washington Controls and Destroys Our Health Care. Strategic Book Publishing and Rights Agency: Corpus Christi, TX. Link: http://bit.ly/2MLkPxq

4. Merritt Hawkins Team (2017) National Healthcare Expenditures Expected to Reach $\$ 5.5 T$ by $2026-$ Physician Appointment Wait Times \& Medicaid and Medicare Acceptance Rates. MerrittHawkins.com.

5. Waldman D (2019) Effect on Patient Care H.R. 1384 'Medicare for All. Texas Public Policy Foundation. Link: http://bit.ly/33LNhGj

6. Waldman D (2019) Curing the Cancer in U.S. Healthcare: StatesCare and MarketBased Medicine. KDP Publishing

7. Paavola A (2018) \$28k: The average price a family of 4 will spend on healthcare in 2018. Beckers Hospital Review. Link: http://bit.ly/2J1xOKi

8. VA Office of Inspector General (2015) Review of Alleged Mismanagement at the Health Eligibility Center. Link: http://bit.ly/31 xESVN
9. Nicholas H (2016) Hundreds on Medicaid Waiting List in Illinois Die While Waiting for Care. Illinois Policy. Link: http://bit.ly/2p2OuKT

10. Waldman D (2017) California wants single payer and Texas wants free market - say hello to 'StatesCare'. Hill. Link: http://bit.ly/33TnLiN

11. New bill looks to clear path for state universal health care. Mynorthwest.com Link: http://bit.ly/35V4v6m

12. Tullus P (2017) Can California Go Single-Payer? American Prospect. Link: http://bit.ly/2p00zyv

13. Waldman D (2016) Single Payer Won't Save Us. Gatekeeper Press: Columbus, $\mathrm{OH}$.

14. Editorial Staff (2018) Americans Are Migrating in Droves to Low-Tax States. Investor's Business Daily. Link: http://bit.ly/2p0Ozyv

15. Editorial Staff (2018) How much did the US spend on health care last year? \$3.5T, according to CMS. Daily Briefing. Link: http://bit.ly/2Ja4a5P

16. Waldman D (2018) Americans can be entitled or free- but not both. Hill. Link: http://bit.ly/35T4P5u

17. Waldman D (2017) A doctor's straight talk: America, your health care is not a federal responsibility. Fox News. Link: https://fxn.ws/2J8EvKS
Discover a bigger Impact and Visibility of your article publication with Peertechz Publications

\section{Highlights}

- Signatory publisher of ORCID

* Signatory Publisher of DORA (San Francisco Declaration on Research Assessment)

- Articles archived in worlds' renowned service providers such as Portico, CNKI, AGRIS, TDNet, Base (Bielefeld University Library), CrossRef, Scilit, J-Gate etc.

* Journals indexed in ICMJE, SHERPA/ROMEO, Google Scholar etc.

* OAI-PMH (Open Archives Initiative Protocol for Metadata Harvesting)

* Dedicated Editorial Board for every journal

* Accurate and rapid peer-review process

* Increased citations of published articles through promotions

* Reduced timeline for article publication

Submit your articles and experience a new surge in publication services (https://www.peertechz.com/submission).

Peertechz journals wishes everlasting success in your every endeavours.

Copyright: @ 2019 Waldman D. This is an open-access article distributed under the terms of the Creative Commons Attribution License, which permits unrestricted use distribution, and reproduction in any medium, provided the original author and source are credited. 